\title{
Autoregulation of nitrogenase expression in Klebsiella pneumoniae
}

\author{
Susan Hill and Eugene P. Kavanagh \\ Author for correspondence: Susan Hill. Tel: +44273 678242. Fax: +44 273678133. \\ e-mail: SUSAN.HILL@BBSRC.AC.UK
}

Nitrogen Fixation

Laboratory, University of Sussex, Brighton BN1 9RQ, UK

\begin{abstract}
An investigation into the influence of $\mathrm{N}_{2}$ on the expression of Klebsiella pneumoniae nitrogenase has led to a reassessment of the role of the nitrogenase MoFe protein in autoregulation. Anaerobic derepression of nitrogenase $\left(\mathrm{C}_{2} \mathrm{H}_{2}\right.$-reducing) activity, of NifD and $\mathrm{K}$ polypeptides, and of nifH-lac expression, following the removal of excess $\mathrm{NH}_{4}^{+}$, were greater under $\mathbf{N}_{\mathbf{2}}$ than Ar. This enhancement occurred in Nif' but not in Nif- strains, and in Nif ${ }^{+}$strains was prevented by $\mathrm{C}_{2} \mathrm{H}_{2}$, an inhibitor of $\mathrm{N}_{2}$ fixation. Thus $\mathrm{N}_{2}$ fixation is important for maintaining derepression. Derepression of nifH-lac under Ar in various $\mathrm{Nif}^{+}$and $\mathrm{Nif}^{-}$strains (including $\mathrm{NifH}^{-}, \mathrm{NifD}^{-}$, $\mathrm{NifB}^{-}$and $\mathrm{NifL}^{-}$mutants) and of wild-type lac under $\mathbf{N}_{2}$ or $\mathrm{Ar}$ in a Nif ${ }^{+}$strain were measured to investigate the regulation. The mechanism regulating the enhancement under $\mathbf{N}_{\mathbf{2}}$ neither involved the MoFe protein of nitrogenase, as proposed by Dixon et al. (1980, Nature 286, 128-132), nor the nifL product, but was probably due to a general upgrading of the $\mathbf{N}$ status. Moreover, during batch growth limited by a non-repressing fixed $\mathbf{N}$ source, the levels of nifH-lac expression in the $\mathrm{Nif}^{+}$and Nif- strains suggested that the nifH gene product (or Fe protein) may have a positive autoregulatory function.
\end{abstract}

Keywords: Klebsiella pneumoniae, nitrogenase, anaerobic derepression, nifH-lac expression, autoregulation

\section{INTRODUCTION}

The ability to fix $\mathrm{N}_{2}$ occurs widely amongst obligate anaerobic, obligate aerobic, and facultative anaerobic prokaryotes (Young, 1992). The nitrogenase enzymes responsible for this fixation are very similar in structure and function (Eady, 1991). Since all are damaged irreversibly by oxygen they require anaerobic conditions as well as needing a source of reducing power and a large amount of ATP.

The structure of the nitrogen fixation genes (nif) and the mode of their regulation have been most studied in the facultative anaerobe Klebsiella pneumoniae (Dixon, 1984). Similarities and differences are found in other diazotrophs (Merrick, 1993). K. pneumoniae fixes $\mathrm{N}_{2}$ under anaerobic or microaerobic conditions. The latter is beneficial as regards the efficiency of the utilization of a fermentable carbon source for diazotrophy (Hill, 1976). In K. pneumoniae, 20 nif genes are arranged in eight transcriptional units and make up the contiguous nif cluster of $23 \mathrm{~kb}$ (Dixon, 1984; Merrick, 1993; Dean \& Jacobson, 1992). The products of the nifL. $A$ operon have regulatory functions. Although the structural genes (nifHDK) are part of a single operon, the synthesis and activity of nitrogenase requires at least 12 other nif gene products, including those required to generate a suitable source of reducing power (Dean \& Jacobson, 1992).

Derepression of nif in $K$. pneumoniae occurs under $\mathrm{N}$ limitation (Tubb \& Postgate, 1973) and is associated with anaerobiosis (Eady et al., 1978), or very low oxygen concentrations (Hill et al., 1984). Transcription of nif is under the general nitrogen regulatory control (ntr) of enterics, and is mediated by a form of RNA polymerase that contains the $r p o N$-encoded $\sigma$ factor (Merrick, 1992; Kustu et al., 1989; Buck \& Cannon, 1992). Transcription from the nif $L A$ promoter is activated by the $\mathrm{NtrC}$ protein (Merrick, 1992; Kustu et al., 1989) as well as being influenced by the superhelical topology of the DNA (Whitehall et al., 1992). Transcription from all other nif operons is activated by the nif $A$ product (Merrick, 1992; Buck, 1990). The activity of the nif $A$ product is inhibited by the nif $L$ product in response to repressive levels of environmental fixed $\mathrm{N}$ or $\mathrm{O}_{2}$ (Merrick et al., 1982; Merrick, 1992; Hill, 1988). During derepression tran- 
Table 1. Strains and plasmids

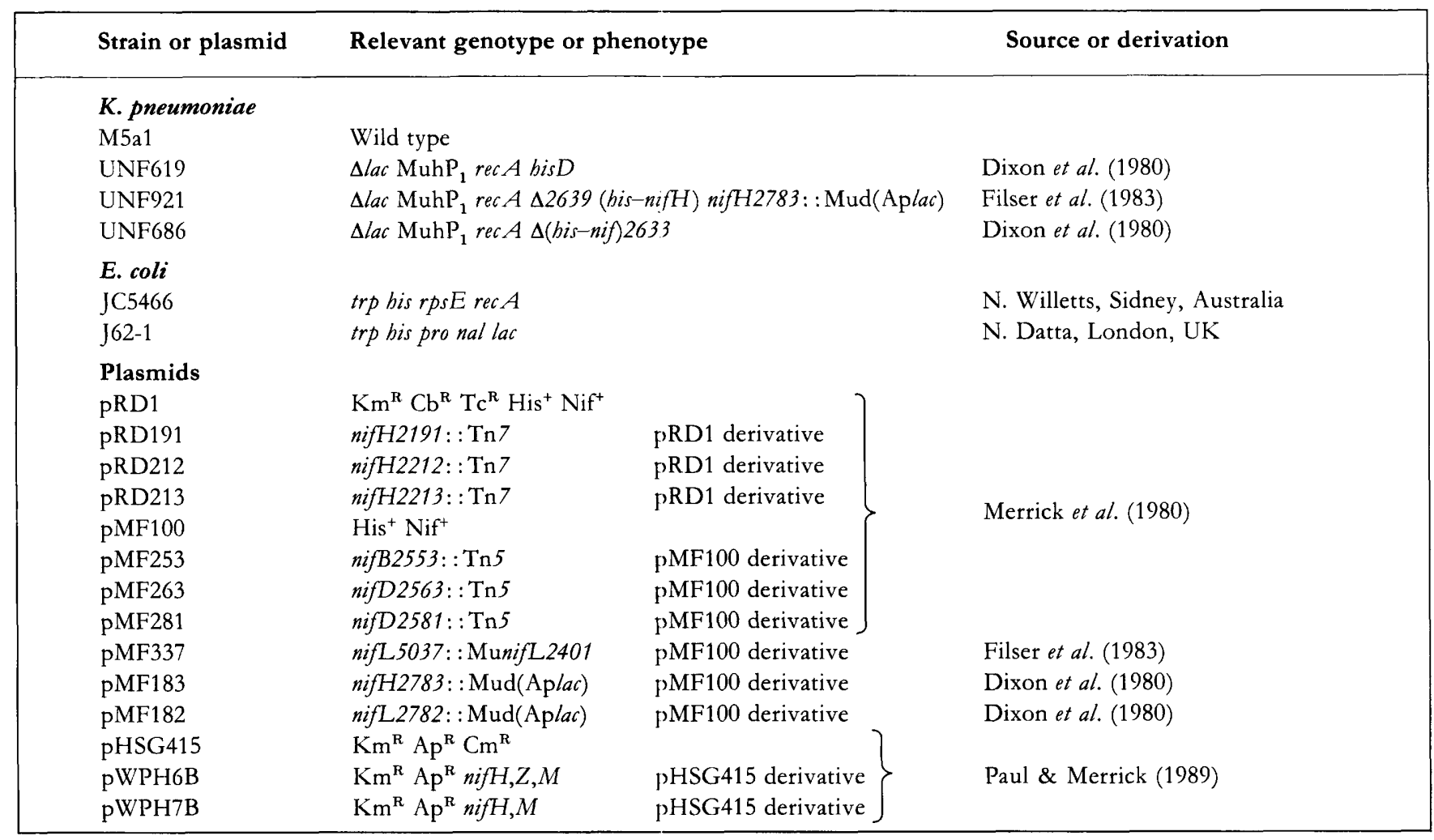

scription of the nif $\mathrm{L} A$ operon precedes that of nifHDKY and other nif operons tested (Cannon et al., 1985), but at least an hour elapses after nifHDKY transcription and translation are detected and before nitrogenase activity can be measured. This lag probably reflects the complexity of the processing of the polypeptides (Govezensky et al., 1991).

Two additional phenomena apparently control nitrogenase synthesis: hyperderepression, which occurs when the supply of $\mathrm{N}_{2}$ limits growth (Postgate, 1982; Hill, 1992), and autoregulation, which is hypothetically effected by the MoFe protein of nitrogenase at the nifH promoter (Dixon et al., 1980). The data presented here show that the maintenance of nitrogenase synthesis during nif derepression requires $\mathrm{N}_{2}$ fixation. This observation has led to a reassessment of the role of the nitrogenase $\mathrm{MoFe}$ protein in autoregulation. Some of this work was summarized earlier (Hill \& Kavanagh, 1988).

\section{METHODS}

Bacterial strains and plasmids. Bacterial strains and plasmids are listed in Table 1 . His ${ }^{+}-$or kanamycin- $(\mathrm{Km})\left(30 \mu \mathrm{g} \mathrm{m}^{-1}\right)$ resistant transconjugants of $K$. pneumoniae were selected from matings (Cannon, 1980) with an Escherichia coli strain (JC5466 or J62-1), which carried the desired plasmid. Strains receiving plasmids carrying $\operatorname{Tn} 7$ were checked for resistance to trimethoprim $\left(20 \mu \mathrm{g} \mathrm{ml}^{-1}\right)$. Transformations of strain UNF686 with pHSG415, pWPH6B or pWPH7B were performed by the method of Merrick et al. (1987). Transformants were selected by resistance to $\mathrm{Km}\left(30 \mu \mathrm{g} \mathrm{ml}^{-1}\right)$, and were checked for the presence of the desired plasmids by EcoR 1 restriction analysis (Maniatis et al., 1982).

Growth and derepression conditions. Strains were maintained on either nutrient agar or minimal glucose medium (Cannon, 1980 ) containing $\mathrm{Km}$ when required. Anaerobic growth (at $28^{\circ} \mathrm{C}$ ) for the derepression experiments was initiated with a $5 \%$ $(\mathrm{v} / \mathrm{v})$ inoculation from an $8 \mathrm{~h}$ aerobic nutrient broth culture in $50 \mathrm{ml}$ of a nitrogen-free medium (NFDM) (Cannon, 1980) supplemented with $15 \mathrm{mM}\left(\mathrm{NH}_{4}\right)_{2} \mathrm{SO}_{4}$. Cultures were bubbled gently with $1 \%(\mathrm{v} / \mathrm{v}) \mathrm{CO}_{2}$ in $\mathrm{N}_{2}$. Cultures were harvested at room temperature by centrifugation for $15 \mathrm{~min}$ at $800 \mathrm{~g}$. After decanting the supernatant, the walls of the vessel were wiped with a kleenex tissue to remove residual liquid. The concentrated cells were resuspended under Ar to a biomass density of about $0.45 \mathrm{mg}$ protein $\mathrm{ml}^{-1}$ in NFDM. When required, IPTG $(1 \mathrm{mM})$ was added immediately after resuspension. Where the effect of $\mathrm{C}_{2} \mathrm{H}_{2}$ on nitrogenase derepression was being examined the procedure was as described previously (Hill et al., 1984). Anaerobic N-limited growth was established in NFDM supplemented with either serine $\left(100 \mu \mathrm{g} \mathrm{ml}^{-1}\right)$ or vitamin-free casamino acids (Difco) $\left(400 \mu \mathrm{g} \mathrm{ml}^{-1}\right)$ and $\mathrm{Km}$, when required, that had been inoculated $(5 \%, v / v)$ from an $8 \mathrm{~h}$ aerobic nutrient broth culture. Anaerobic conditions were achieved by bubbling $5 \mathrm{ml}$ cultures in universal bottles under either $\mathrm{N}_{2}$ or $\mathrm{Ar}$, both containing $1 \%(\mathrm{v} / \mathrm{v}) \mathrm{CO}_{2}$, at $28^{\circ} \mathrm{C}$ for $18 \mathrm{~h}$. N-limited growth in bijou bottles capped with Subaseal closures was as described by Dixon et al. (1980). The conditions during this growth $\left(18 \mathrm{~h}\right.$ at $\left.28^{\circ} \mathrm{C}\right)$ were likely to be microaerobic rather than anaerobic, because there was a small amount of air trapped above the medium.

Immunoblot analysis. Polypeptides, separated by SDS-PAGE using $12 \%(\mathrm{w} / \mathrm{v})$ polyacrylamide gels, were transferred to Immobilon-P membrane (Millipore) $(0.45 \mu \mathrm{m})$ by the semi-dry 
blot method (Tovey \& Baldro, 1987). Blots were strained with Auro Dye forte (Janssen) and then developed with rabbit antiserum raised to $K$. pneumoniae NifDK polypeptides (Serotec) and sheep anti-rabbit conjugate peroxidase (Serotec) using the ECL Western-blotting detection system (Amersham International) with HRG X-ray film (Fuji).

Assays. $\beta$-Galactosidase activity was measured as described by Miller (1972). Nitrogenase $\left(\mathrm{C}_{2} \mathrm{H}_{2}\right.$-reducing $)$ activity was measured either after $\mathrm{N}$-limited growth as described by Dixon et al. (1980), or anaerobically in $1 \mathrm{ml}$ samples removed from derepression treatments or from $\mathrm{N}$-limited anaerobic growth by the method described previously (Hill et al., 1990), except that the time course was from 20 to $30 \mathrm{~min}$, substrates were not added and $10 \%(\mathrm{v} / \mathrm{v}) \mathrm{C}_{2} \mathrm{H}_{2}$ in either Ar or $\mathrm{N}_{2}$ was the gas phase. Biomass was measured, routinely, by $\mathrm{OD}_{600}$, and protein content was calculated from a determined relationship between $\mathrm{OD}$ and bacterial protein (see Smith et al., 1988). A ratio for a particular parameter, under $\mathrm{N}_{2} /$ under $\mathrm{Ar}$, or the percentage value related to the relevant wild type was calculated for each experiment, and then the values from the replicated experiments were used to compute the mean and SE.
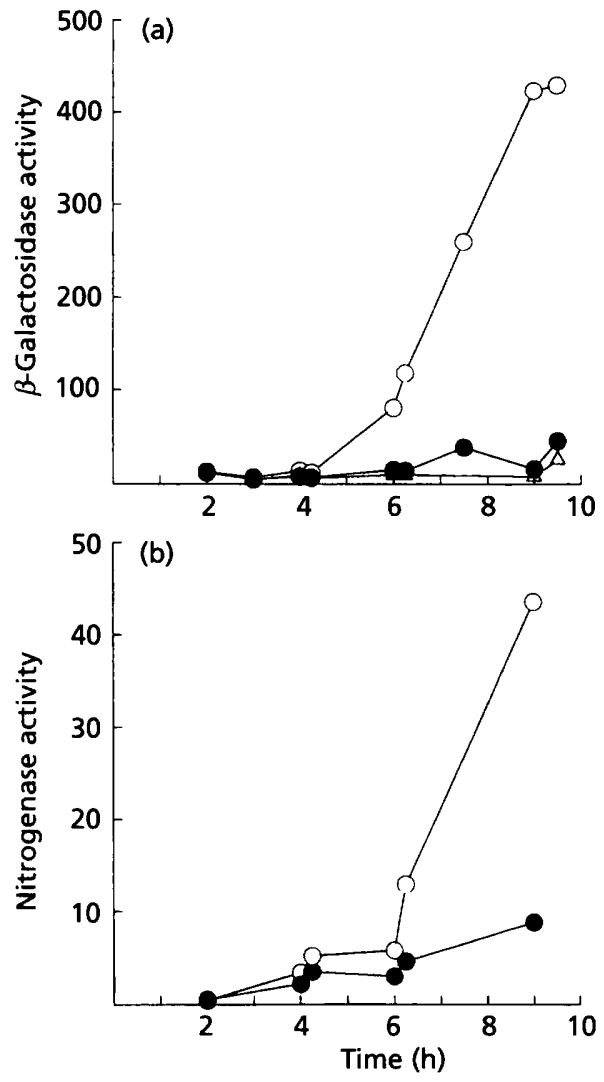

Fig. 1. Effect of $\mathrm{N}_{2}$ on the derepression in NFDM of (a) wildtype lac and (b) nitrogenase in strain M5a1. During derepression carried out in either the presence of IPTG $(O, 0)$ or the absence of IPTG $(\triangle)$ organisms were exposed to either $\mathrm{N}_{2}$ (open symbols) or $\mathrm{Ar}$ (closed symbols). Derepression of nitrogenase under either $\mathrm{N}_{2}$ or $\mathrm{Ar}$ was not affected by the presence of IPTG. Samples were removed for assays of $\beta$ galactosidase (Miller units) or specific nitrogenase $\left(\mathrm{C}_{2} \mathrm{H}_{2}-\right.$ reducing) [nmol $\mathrm{C}_{2} \mathrm{H}_{4}$ produced (mg protein) ${ }^{-1} \mathrm{~min}^{-1}$ ] activities.
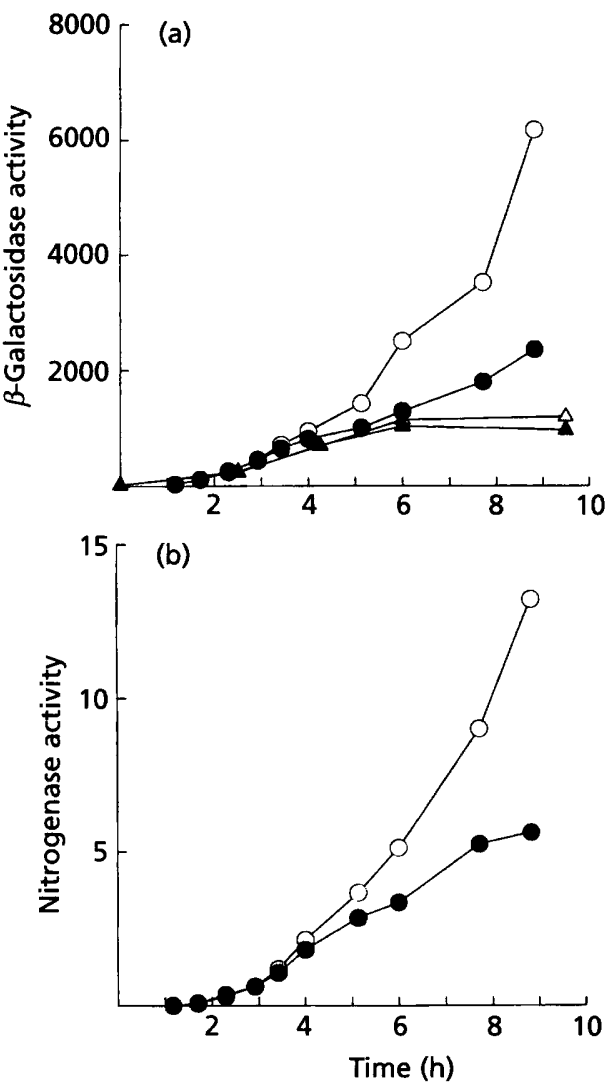

Fig. 2. Effect of $\mathrm{N}_{2}$ on the derepression of (a) nifH-lac in the $\mathrm{Nif}^{+}$strain UNF619(pMF183) $(\mathrm{O}, 0)$ and in the $\mathrm{Nif}^{-}$strain UNF686(pMF183) $(\triangle, \Delta)$ and of (b) nitrogenase in the $\mathrm{Nif}^{+}$ strain UNF619(pMF183). During derepression, carried out under either $N_{2}$ (open symbols) or Ar (closed symbols), samples were removed for assays of either $\beta$-galactosidase (Miller units) or specific nitrogenase [nmol $\mathrm{C}_{2} \mathrm{H}_{4}$ produced (mg protein) ${ }^{-1} \mathrm{~min}^{-1}$ ] activities.

\section{RESULTS AND DISCUSSION}

\section{Nitrogenase derepression and $\mathbf{N}$ starvation}

When $K$. pneumoniae is grown anaerobically with excess $\mathrm{NH}_{4}^{+}$, harvested and then resuspended anaerobically in NFDM, nif is derepressed, and nitrogenase activity is detected 2-3 h later (Eady et al., 1978; Cannon et al., 1985). The addition of aspartate, glutamine or casamino acids to NFDM speeds up derepression (see Tubb \& Postgate, 1973, and references therein; Nair \& Eady, 1984) indicating that the rate of derepression is limited by the availability of fixed $\mathrm{N}$. Likewise, $\mathrm{N}_{2}$ fixation, once initiated, might influence the derepression kinetics in NFDM.

The kinetics of nitrogenase derepression in the wild type (M5a1) and in various $\mathrm{Nif}^{+}$derivatives were followed in NFDM under either $\mathrm{N}_{2}$ or Ar. After the appearance of nitrogenase $\left(\mathrm{C}_{2} \mathrm{H}_{2}\right.$-reducing $)$ activity, the subsequent derepression was faster under $\mathrm{N}_{2}$ than under Ar (Figs 1b, $2 b$ and $3 b)$. The ratios of nitrogenase activities under $\mathrm{N}_{2}$ /under Ar were greater than 1 after 6 h derepression in 
$500-(a)$

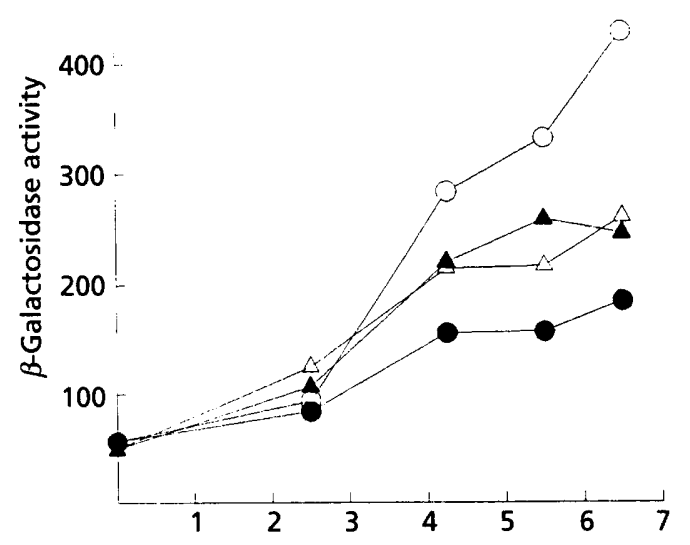

$40\ulcorner$ (b)

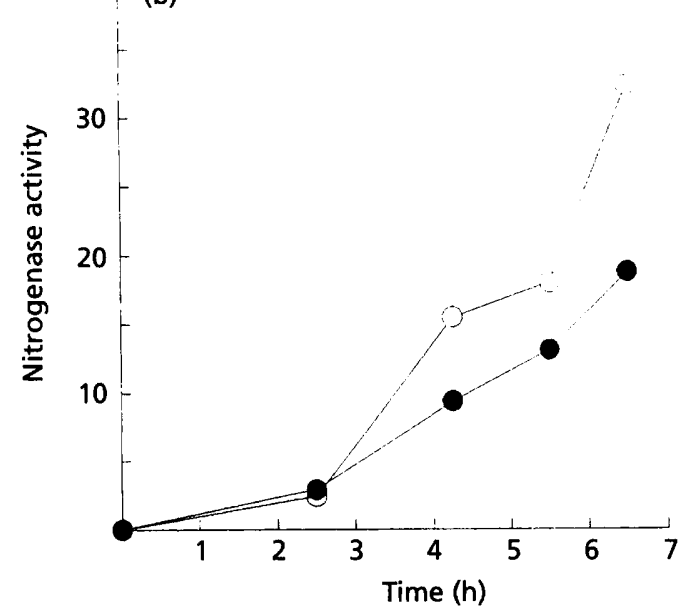

Fig. 3. Effect of $\mathrm{N}_{2}$ on the derepression of (a) nifH-lac in the $\mathrm{Nif}^{+}$strain UNF921(pMF100) $(O, O)$ and the $\mathrm{Nif}^{-}$strain UNF921(pMF263) $(\triangle, \Delta)$ and of (b) nitrogenase in strain UNF921(pMF100). During derepression, carried out under $\mathrm{N}_{2}$ (open symbols) or Ar (closed symbols), samples were removed for assays of $\beta$-galactosidase (Miller units) or specific nitrogenase [nmol $\mathrm{C}_{2} \mathrm{H}_{4}$ produced (mg protein) ${ }^{-1} \mathrm{~min}^{-1}$ ] activities.

all the $\mathrm{Nif}^{+}$derivatives tested (Table 2). Higher levels of nif $\mathrm{H}$ and $D$ polypeptides were found under $\mathrm{N}_{2}$ compared to that under Ar (Fig. 4). Thus the rate of nitrogenase synthesis was enhanced under $\mathrm{N}_{2}$ compared to that under Ar.

The kinetics of $n i f H-l a c$ derepression were also measured in $\mathrm{Nif}^{+}$strains. As with nitrogenase, the rate of appearance of $\beta$-galactosidase activity was greater under $\mathrm{N}_{2}$ than under $\mathrm{Ar}$, once nitrogenase activity had been detected (Figs $2 \mathrm{a}$ and $3 \mathrm{a}$ ). The ratios of activities under $\mathrm{N}_{2}$ /under Ar were greater than 1 after $6 \mathrm{~h}$ derepression in the $\mathrm{Nif}^{+}$ derivatives tested (Table 3 ). Thus, the enhancement of nitrogenase derepression by $\mathrm{N}_{2}$ might in part reside at the level of transcription.

If $\mathrm{N}_{2}$ fixation is essential then $\mathrm{C}_{2} \mathrm{H}_{2}$, an inhibitor of $\mathrm{N}_{2}$ fixation (Hwang et al., 1973), should prevent the enhanced derepression of nitrogenase under $\mathrm{N}_{2}$. The presence of $\mathrm{C}_{2} \mathrm{H}_{2}$ prevented the greater expression of nif $\mathrm{H}$-lac and of nitrogenase activity in Nif $^{+}$strains during $6 \mathrm{~h}$ derepression under $\mathrm{N}_{2}$ compared to that under $\operatorname{Ar}$ (Table 4). The ratios under $\mathrm{N}_{2} /$ under $A$ r of both $\beta$-galactosidase and nitrogenase were lowered to near unity by the presence of $\mathrm{C}_{2} \mathrm{H}_{2}$. Thus $\mathrm{N}_{2}$ fixation is required for the enhanced derepression of nitrogenase under $\mathrm{N}_{2}$.

\section{Regulation of nitrogenase derepression by $\mathrm{N}_{2}$ fixation}

Three possibilities were investigated to determine how $\mathrm{N}_{2}$ fixation might improve anaerobic derepression of nif $\mathrm{H}-\mathrm{lac}$ and nitrogenase. Firstly, a modification of the nifL product could increase the effective concentration of the nif $A$ product for $n i f$ transcription (Merrick et al., 1982; Filser et al., 1983; Drummond \& Wootton, 1987). This was ruled out because the behaviour of a $\mathrm{NifL}^{-} \mathrm{Nif}^{+}$ strain, UNF921(pMF337), was similar to that of the isogenic wild type $\mathrm{NifL}^{+} \mathrm{Nif}^{+}$, UNF921(pMF100). In both strains the levels of nifH-lac and of nitrogenase activity after $6 \mathrm{~h}$ under $\mathrm{N}_{2}$ were greater than those under $\operatorname{Ar}$ (Tables 2 and 3). Secondly, regulation by the products of the nitrogen regulatory genes $n \operatorname{tr} B C$ (Merrick, 1992) might improve nif $\mathrm{L} A$ expression and hence increase nitrogenase derepression. The slightly greater nif L-lac expression we observed after $6 \mathrm{~h}$ derepression under $\mathrm{N}_{2}$ compared to that under $\mathrm{Ar}$ in a $\mathrm{Nif}^{+}$background [UNF619(pMF182)], but not in a Nif background [UNF686(pMF182)] (Table 5) was consistent with this possibility. Thirdly, $\mathrm{N}_{2}$ fixation by upgrading the $\mathrm{N}$ status might stimulate translation. The kinetics of IPTGinduced expression of wild type lac during nitrogenase derepression under $\mathrm{N}_{2}$ was compared with that under $\mathrm{Ar}$ in the $\mathrm{Nif}^{+}$strain M5a1. A marked increase in $\beta$ galactosidase activity only occurred under $\mathrm{N}_{2}$ when nitrogenase was detected (Fig. 1). Thus $\mathrm{N}_{2}$ fixation by improving the $\mathrm{N}$ status probably stimulated lac translation. This stimulation could account for the enhanced expression of nifL-lac and nifH-lac under $\mathrm{N}_{2}$, as these fusions are of the transcriptional type. Moreover, because nitrogenase polypeptide synthesis was also greater under $\mathrm{N}_{2}$ compared to that under $\mathrm{Ar}$ (Fig. 4) the elevation in $\mathrm{N}$ status probably improved translation in general.

\section{Autoregulation and the MoFe protein of nitrogenase}

The evidence presented above, indicated that the marked difference in nifH-lac expression during derepression under $\mathrm{N}_{2}$ compared to that under $\mathrm{Ar}$ in $\mathrm{Nif}^{+}$strains can be accounted for by an improvement in $\mathrm{N}$ status increasing, at least, translation. These results prompted a reassessment of the role of the MoFe protein in autoregulation (Dixon et al., 1980). The evidence of Dixon et al. (1980) for this autoregulation rested upon four observations. Firstly, the expression of nif $\mathrm{H}$-lac during derepression under $\mathrm{N}_{2}$ in the $\mathrm{Nif}^{+}$strain UNF619(pMF183) was much greater than in the Nif strain UNF686(pMF183). The latter strain can not make the $n i f H, D$ and $K$ products. Secondly, a similar difference 
Table 2. Nitrogenase activity in $\mathrm{Nif}^{+}$strains after $6 \mathrm{~h}$ derepression under either $\mathrm{N}_{2}$ or $\mathrm{Ar}$

Results are mean values \pm SE and the number of different experiments is indicated under $n$.

\begin{tabular}{|c|c|c|c|c|c|c|}
\hline Strain & Relevant genotype & Plasmid & $\begin{array}{l}\text { Relevant } \\
\text { genotype }\end{array}$ & $n$ & $\begin{array}{c}\text { Ratio of } \\
\text { activities under } \\
\mathbf{N}_{2} / \text { under Ar }\end{array}$ & $\begin{array}{c}\text { Specific activity } \\
\text { under Ar } \\
{\left[\text { nmol } \mathrm{C}_{2} \mathrm{H}_{4} \text { produced }\right.} \\
\text { (mg protein) })^{-1} \mathrm{~min}^{-1} \text { ] }\end{array}$ \\
\hline M5a1 & Wild type & - & & 5 & $2 \cdot 5 \pm 0.5$ & $4.9 \pm 0.7$ \\
\hline UNF921 & $\Delta($ bis-nifH $)$ nifH: : lac & pRD1 & Wild type & 4 & $2 \cdot 3 \pm 0 \cdot 1$ & $10 \cdot 0 \pm 2 \cdot 5$ \\
\hline UNF921 & $\Delta($ bis-nifH $)$ nifH: : lac & pMF100 & Wild type & 8 & $2 \cdot 1 \pm 0 \cdot 1$ & $15 \cdot 2 \pm 0 \cdot 8$ \\
\hline UNF921 & $\Delta($ bis-nifH $)$ nif $H:: l a c$ & pMF337 & nifL2401 & 1 & $2 \cdot 5$ & $1 \overline{3} \cdot 0$ \\
\hline UNF619 & Wild type & pMF183 & nifH: : lac & 2 & $1 \cdot 4 \pm 0 \cdot 2$ & $3 \cdot 3 \pm 0 \cdot 1$ \\
\hline UNF619 & Wild type & pMF182 & nifL: : lac & 2 & $2 \cdot 5 \pm 0 \cdot 3$ & $6 \cdot 9 \pm 3 \cdot 2$ \\
\hline
\end{tabular}

(a)

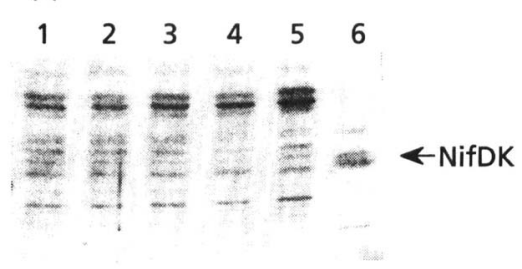

(b)

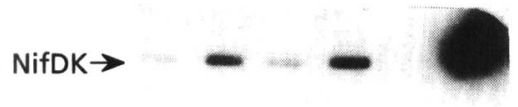

Fig. 4. A Western blot of wild-type (M5a1) bacterial protein harvested at the end of $6 \mathrm{~h}$ derepression under either $\mathrm{N}_{2}$ or Ar. Polypeptides, separated by SDS-PAGE, were blotted, stained by Aurodye forte (a) and then this blot was analysed for NifD and $K$ polypeptides by ELISA (b) (see Methods). Lanes: 1 and 3 , derepressed under $\mathrm{Ar} ; 2$ and 4 , derepressed under $\mathrm{N}_{2} ; 5, \mathrm{NH}_{4}^{+-}$ grown M5a1 harvested before derepression; 6 , MoFe protein of $K$. pneumoniae nitrogenase. Lanes 1, 2 and 6 were loaded with $1.5 \mu \mathrm{g}$ protein and lanes 3,4 and 5 were loaded with $3 \mu \mathrm{g}$ protein.

in nif $\mathrm{H}$-lac expression was observed in these $\mathrm{Nif}^{+}$and $\mathrm{Nif}^{-}$strains after $\mathrm{N}$-limited growth on $100 \mu \mathrm{g}$ serine $\mathrm{ml}^{-\mathbf{1}}$. Thirdly, this greater expression required the presence of Mo. Fourthly, the levels of nif $\mathrm{H}$-lac expression during Nlimited growth in two out of three nif $\mathrm{H}$ insertion mutants were atypical.

The first observation of Dixon et al. (1980) might be accounted for by our evidence indicating that the expression of nifH-lac during derepression in $\mathrm{Nif}^{+}$strains is enhanced by $\mathrm{N}_{2}$ fixation. The kinetics of derepression under $\mathrm{Ar}$ and under $\mathrm{N}_{2}$ were compared in the strains used by Dixon et al. (1980) [the Nif ${ }^{+}$strain UNF619(pMF183) and the Nif strain UNF686(pMF183)] (Fig. 2). We confirmed their kinetics under $\mathrm{N}_{2}$, which showed that the rate of nifH-lac expression was much faster in the $\mathrm{Nif}^{+}$ than that in the Nif ${ }^{-}$strain (Fig. 2a). As expected, our data showed that only in the $\mathrm{Nif}^{+}$strain was nifH-lac derepression enhanced by $\mathrm{N}_{2}$. A comparison of the kinetics under $\mathrm{Ar}$, where the $\mathrm{N}$ status could not be improved by $\mathrm{N}_{2}$ fixation, revealed that the level of expression was higher in the $\mathrm{Nif}^{+}$strain. This result suggested that the Nif ${ }^{-}$strain UNF686(pMF183) lacked a component which helps to drive nifH-lac expression in UNF619(pMF183). However, these strains differ not only in the ability of the $\mathrm{Nif}^{+}$strain UNF619(pMF183) to make the MoFe protein of nitrogenase, but also the latter carries all the nif genes on the chromosome, whereas the chromosome of UNF686(pMF183) carries none. The additional copy of nif $\mathrm{L} A$ in UNF619(pMF183) could have boosted nifH-lac expression.

To eliminate the possible involvement of gene dosage by nif $\mathrm{L} A$ a similar experiment was performed with the $\mathrm{Nif}^{+}$ strain UNF921(pMF100) and the isogenic Nif strain UNF921(pMF263), which carries a Tn5 insertion in nifD. Again the results showed that in the $\mathrm{Nif}^{+}$strain, but not in the $\mathrm{Nif}^{-}$strain, nifH-lac expression was faster under $\mathrm{N}_{2}$ than under $\mathrm{Ar}$ (Fig. 3a). When the kinetics under Ar were compared, the level of expression was not higher in the strain making the $\mathrm{MoFe}$ protein of nitrogenase [UNF921(pMF100)] (Fig. 3a). This result was confirmed in a number of other strains with $\operatorname{Tn} 5$ insertions in the nif $H$, nifD or nifB (Table 3). Thus, we were unable to detect autoregulation of nifH-lac expression by the Fe or $\mathrm{MoFe}$ proteins of nitrogenase under conditions of $\mathrm{N}$ starvation, during derepression under Ar.

The second observation of Dixon et al. (1980) showed that nifH-lac expression in the $\mathrm{Nif}^{+}$strain UNF619(pMF183) was much greater than in the Nif strain UNF686(pMF183) during N-limited growth on $100 \mu \mathrm{g}$ serine $\mathrm{ml}^{-1}$. We also found a similar difference in nifH-lac expression in these strains when grown under the microaerobic conditions (see Methods) used by Dixon et al. (1980), and when grown under $\operatorname{Ar}$ (Table 6). The extra copy of nif $A$ in the $\mathrm{Nif}^{+}$strain UNF619(pMF183) (as indicated above) may have contributed, in part, to the greater expression in this $\mathrm{Nif}^{+}$strain compared to that in the Nif strain UNF686(pMF183). When this experiment was performed with isogenic strains, the expression of 
Table 3. nifH-lac derepression in UNF921 [ $\Delta\left(\right.$ his-nifH)nifH2783: : Mud(Aplac)] carrying a $\mathrm{Nif}^{+}$or a Nif $^{-}$plasmid under either $\mathrm{N}_{2}$ or $\mathrm{Ar}$

Results are mean values \pm SE and the number of different experiments is indicated under $n$. Figures in parentheses show the activities in Miller units (mean \pm SE).

\begin{tabular}{|c|c|c|c|c|c|}
\hline \multirow[t]{2}{*}{ Plasmid } & \multirow{2}{*}{$\begin{array}{c}\text { Nif } \\
\text { phenotype }\end{array}$} & \multirow{2}{*}{$\begin{array}{l}\text { Relevant } \\
\text { genotype }\end{array}$} & \multirow[t]{2}{*}{$n$} & \multicolumn{2}{|c|}{$\beta$-Galactosidase activity at $6 \mathrm{~h}$} \\
\hline & & & & Ratio under $\mathrm{N}_{2} /$ under $\mathrm{Ar}$ & Under Ar (\%) \\
\hline pMF100 & + & Wild type & 8 & $3 \cdot 16 \pm 0 \cdot 25$ & $100(206 \pm 10)$ \\
\hline pMF281 & - & nifD2581:: $\operatorname{Tn} 5$ & 2 & $1.06 \pm 0.01$ & $127 \pm 4$ \\
\hline pMF263 & - & nifD2563: : $\operatorname{Tn} 5$ & 3 & $1 \cdot 05 \pm 0.02$ & $121 \pm 6$ \\
\hline pMF253 & - & nifB2553: : $\operatorname{Tn} 5$ & 2 & $1 \cdot 00 \pm 0.04$ & $106 \pm 5$ \\
\hline pMF337 & + & nifL2401 & 2 & $3 \cdot 73 \pm 0.22$ & $78 \pm 9$ \\
\hline pRD1 & + & Wild type & 4 & $2.94 \pm 0.53$ & $100(229 \pm 56)$ \\
\hline pRD191 & - & nifH2191: : $\operatorname{Tn} 7$ & 2 & $0.98 \pm 0.02$ & $156 \pm 25$ \\
\hline pRD212 & - & nifH2212: : Tn7 & 3 & $0.87 \pm 0.07$ & $128 \pm 21$ \\
\hline pRD213 & - & nifH2213: : $\operatorname{Tn} 7$ & 3 & $1 \cdot 05 \pm 0.04$ & $100 \pm 9$ \\
\hline
\end{tabular}

Table 4. Influence of $\mathrm{C}_{2} \mathrm{H}_{2}$ on the $\mathrm{N}_{2}$-enhanced derepression of nifH-lac and nitrogenase in UNF921 $\left[\Delta\left(\right.\right.$ his-nifH)nifH2783: : Mud(Aplac)] carrying a Nif ${ }^{+}$plasmid

Results are mean values $\pm \operatorname{sE}[n=2$ for UNF921(pMF100); $n=1$ for UNF921(pRD1)]. Figures in parentheses show the activities (mean $\pm \mathrm{sE}$ ) for the parameters under Ar in Miller units $\left(\beta\right.$-galactosidase) and $\mathrm{C}_{2} \mathrm{H}_{4}$ produced $(\mathrm{mg} \text { protein })^{-1} \mathrm{~min}^{-1}$ (nitrogenase).

\begin{tabular}{|cccc|}
\hline Plasmid & Presence of & Ratio of parameters at $\mathbf{6} \mathbf{h}$ under $\mathbf{N}_{2} /$ under $\mathbf{A r}$ \\
\cline { 3 - 4 } & $\mathbf{C}_{\mathbf{2}} \mathbf{H}_{2}$ & $\boldsymbol{\beta}$-Galactosidase & Nitrogenase \\
\hline \multirow{2}{*}{ pMF100 } & - & $3 \cdot 07 \pm 0 \cdot 18(193 \pm 26)$ & $1 \cdot 97 \pm 0 \cdot 10(15 \cdot 8 \pm 2 \cdot 3)$ \\
& + & $1 \cdot 07 \pm 0 \cdot 03(147 \pm 6)$ & $0 \cdot 69 \pm 0 \cdot 11(14 \cdot 9 \pm 4 \cdot 1)$ \\
pRD1 & - & $2 \cdot 39(395)$ & $1 \cdot 96(15 \cdot 1)$ \\
& + & $1 \cdot 06(342)$ & $1 \cdot 10(14 \cdot 8)$ \\
\hline
\end{tabular}

Table 5. nifL-lac derepression in a $\mathrm{Nif}^{+}$or a Nif[ $\Delta$ (his-nif $) 2633]$ strain carrying pMF182 [nifL2782: : Mud(Ap/ac)] under either $\mathrm{N}_{2}$ or $\mathrm{Ar}$

Results are mean values $\pm \operatorname{SE}(n=3)$. Figures in parentheses show the activity in Miller units (mean $\pm \mathrm{SE}$ ).

\begin{tabular}{|lccc|}
\hline Strain & $\begin{array}{c}\text { Nif } \\
\text { phenotype }\end{array}$ & \multicolumn{2}{c|}{-Galactosidase activity at $\mathbf{6 ~ h}$} \\
\cline { 3 - 4 } & & $\begin{array}{c}\text { Ratio under } \\
\mathbf{N}_{2} / \text { under Ar }\end{array}$ & $\begin{array}{c}\text { Under Ar } \\
(\%)\end{array}$ \\
\hline UNF619 & + & $1.41 \pm 0.06$ & $100(232 \pm 77)$ \\
UNF686 & - & $0.97 \pm 0.13$ & $205 \pm 97$ \\
\hline
\end{tabular}

nif $\mathrm{H}$-lac in the $\mathrm{NifD}^{-}$or $\mathrm{NifB}^{-}$strains was not lower than that in the relevant wild type (Table 7). Thus, we were unable to demonstrate autoregulation by the $\mathrm{MoFe}$ protein of nitrogenase after $\mathrm{N}$-limited growth on $100 \mu \mathrm{g}$ serine $\mathrm{ml}^{-1}$ under the conditions used by Dixon et al. (1980) or under Ar.

We did not investigate the third observation of Dixon et al. (1980) regarding the requirement for Mo.

The fourth observation of Dixon et al. (1980) concerned the atypical levels of nif $\mathrm{H}$-lac expression during $\mathrm{N}$-limited growth in two out of three nifH insertion mutants. Whereas the expression of nifH-lac in one $\mathrm{NifH}^{-}$ merodiploid (carrying a mutation on pRD213) was lower than in the relevant $\mathrm{Nif}^{+}$wild type, the expression was similar to the wild type in two other $\mathrm{NifH}^{-}$derivatives (these carried mutations on either pRD191 or pRD212). Dixon et al. (1980) suggested that in the latter two mutants the insertions were non-polar, so that synthesis of the MoFe protein could occur. The expression of nifH-lac in strains carrying the same nifH mutations as used by Dixon et al. (1980) was compared with that in the relevant $\mathrm{Nif}^{+}$ strain during $\mathrm{N}$-limited batch growth. Under their growth 
Table 6. nifH-lac expression from pMF183 [nifH2783: :Mud(Aplac)] in either the $\mathrm{Nif}^{+}$ strain UNF619 or the $\mathrm{Nif}^{-}$strain UNF686 [ $\Delta$ (his-nif)2633] after growth on serine $\left(100 \mu \mathrm{g} \mathrm{ml}^{-1}\right)$ under either air (microaerobiosis) or $\mathrm{Ar}$

Results are mean values \pm SE and the number of experiments is indicated under $n$.

\begin{tabular}{|c|c|c|c|c|c|c|c|c|}
\hline \multirow[t]{2}{*}{ Strain } & \multirow[t]{2}{*}{$\begin{array}{c}\text { Nif } \\
\text { phenotype }\end{array}$} & \multicolumn{3}{|c|}{ Potential to synthesize:* } & \multicolumn{4}{|c|}{$\begin{array}{c}\beta \text {-Galactosidase (Miller units) } \\
\text { under: }\end{array}$} \\
\hline & & FeMoco & $\begin{array}{c}\text { NifH } \\
\text { product }\end{array}$ & $\begin{array}{l}\text { NifDK } \\
\text { products }\end{array}$ & Air & $(n)$ & Ar & $(n)$ \\
\hline UNF619 & + & + & + & + & $7948 \pm 921$ & (2) & $6036 \pm 1323$ & (4) \\
\hline UNF686 & - & - & - & - & $536 \pm 72$ & (3) & $1828 \pm 386$ & (4) \\
\hline
\end{tabular}

* See Table 7.

Table 7. nifH-lac expression in UNF921 [ $\Delta$ (his-nifH)nifH2783: : Mud(Ap/ac)] carrying either a Nif $^{+}$or a Nif ${ }^{-}$plasmid after growth on serine $\left(100 \mu \mathrm{g} \mathrm{ml}^{-1}\right)$ under either air (microaerobiosis) or Ar

Results are mean values $\underline{\mathrm{SE}}$ and the number of experiments is indicated under $n$. Figures in parentheses show Miller units (mean $\pm \mathrm{SE}$ ).

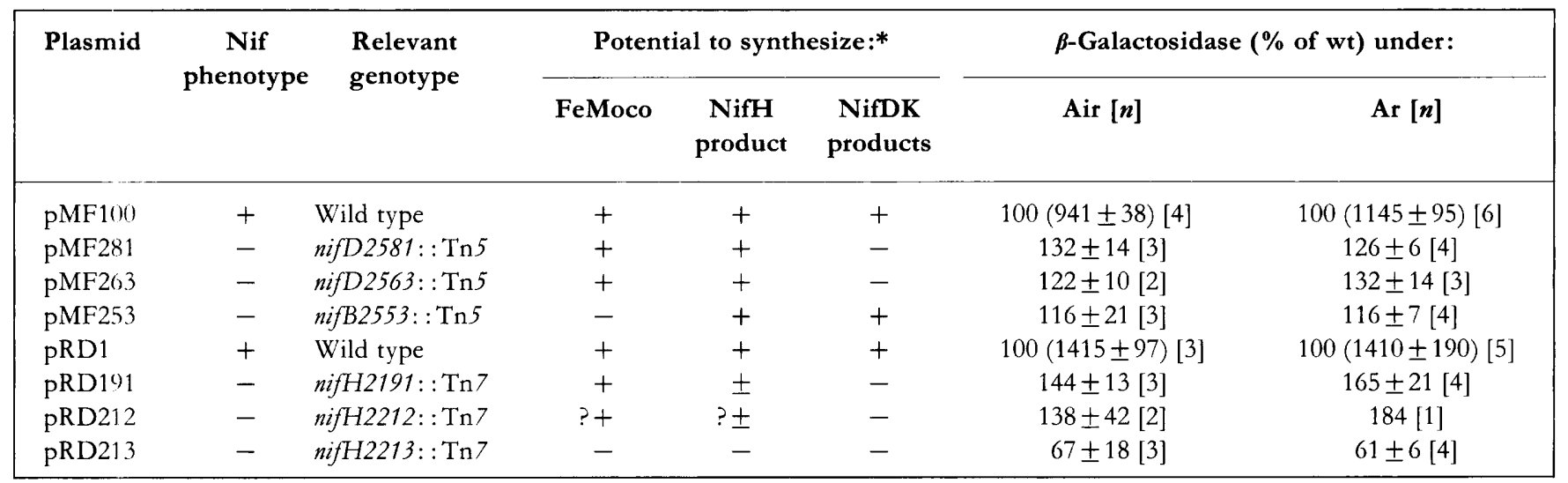

* Capabilities to make the indicated products are represented as: +, able; - , unable; \pm , able to make a mutant form (see text). ?, these capabilities are possible, but have not been determined.

Table 8. nifH-lac expression in strain UNF686 [ $\Delta$ (his-nif)2633] carrying pMF183 [nifH2783: : Mud(Ap/ac)] and either the vector or a recombinant plasmid after growth on serine $\left(100 \mu \mathrm{g} \mathrm{ml}^{-1}\right)$ or casamino acids $\left.(400 \mu \mathrm{g} \mathrm{ml})^{-1}\right)$ under either air (microaerobiosis) or $\mathrm{Ar}$

Results are mean values \pm SE $[n=3$ for experiments with serine; $n=4$ (with pWPH7B) or 6 (with pHSG415 and pWPH6B) for experiments with casamino acids]. Figures in parentheses show Miller units (mean $\pm \mathrm{SE}$ ).

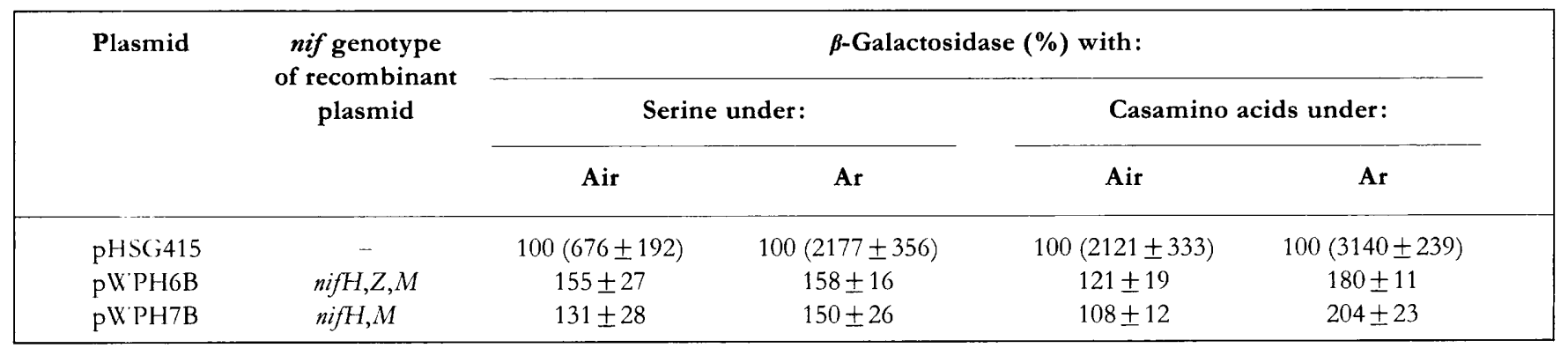

conditions or under Ar (Table 7) our results were similar to those of Dixon et al. (1980); only in UNF921(pRD213) was the expression lower than in the wild type.
The capabilities of these strains to synthesize the nif products needed for the production of the MoFe nitrogenase protein are shown in Table 7 . This analysis 
assumes that the mutations are all polar, and incorporates more recent work with the $\mathrm{NifH}^{-}$mutants (Filler et al., 1986). These authors found that the nifH product made from pRD191, but not that from $\mathrm{pRD} 213$, could support the synthesis of FeMoco. They also demonstrated that a truncated form of the nif $H$ product, which lacked the activity of the Fe protein of nitrogenase, was made from pRD191. They did not examine pRD212. The analysis in Table 7 indicates that the only likely factor missing from strain UNF921(pRD213), but present in the other strains, was a nif $H$ product. Therefore the nif $H$ product rather than the MoFe protein of nitrogenase seemed a more likely candidate for the 'autoregulator'.

\section{Autoregulation and the nifH product}

The effect of the nifH product on nifH-lac expression was tested by introducing a derivative of the low-copy plasmid pHSG415, either pWPH6B or pWPH7B (Paul \& Merrick, 1989), into UNF686(pMF183). UNF686 carries a bis-nif deletion which is complemented by pMF183, except that the latter is $\mathrm{NifH}^{-}, \mathrm{D}^{-}$and $\mathrm{K}^{-}$as it bears the nifH-lac fusion. The recombinant plasmids carry nif $H$ and $M$ (pWPH7B) or nifH, $M$ and $Z$ (pWPH6B), and both encode an active $\mathrm{Fe}$ protein of nitrogenase (Paul \& Merrick, 1989). The expression of nif $H$-lac in these strains was compared with that in the strain carrying the vector pHSG415 after $18 \mathrm{~h}$ of N-limited growth on $100 \mu \mathrm{g}$ serine $\mathrm{ml}^{-1}$ under either $\mathrm{Ar}$ or the assay conditions (microaerobic) of Dixon et al. (1980) (Table 8). The levels were not consistently higher in the strains carrying the recombinant plasmids. The possibility that the inconsistency arose from a slightly unfavourable environmental condition for nif $\mathrm{H}$-lac expression in this background was considered. The quality of the fixed $\mathrm{N}$ source was altered to $400 \mu \mathrm{g}$ casamino acids $\mathrm{ml}^{-1}$, which slightly improved the expression of nif $\mathrm{H}$-lac (Table 8) without altering the biomass. The levels in the strains carrying the recombinant plasmids were then consistently higher than in that carrying the vector, but only under Ar. This suggested that the nif $H$ product or the Fe protein could have a positive autoregulatory role under anaerobic conditions. The involvement of a Fe protein component of nitrogenases in the regulation of nitrogenase synthesis is not novel. The anf $A$-dependent expression of the alternative $\mathrm{Fe}$ nitrogenase of Azotobacter vinelandii requires the presence of $v n f H$ and nif $M$ (Joerger $e t$ al., 1991), and the $\nu n f H$ can be replaced by $A$. vinelandii nif $H$ (Joerger $e t$ al., 1991) or the nifH of a K. pneumoniae background (Jacob \& Drummond, 1993).

\section{ACKNOWLEDGEMENTS}

We thank A. Toukdarian for stimulating discussions, C. A. Gormal for the purified $\mathrm{MoFe}$ protein of $K$. pneumoniae nitrogenase, B. E. Smith and M. J. Merrick for critically reading the manuscript and B. Hall and C. Sterenberg for its preparation.

\section{REFERENCES}

Buck, M. (1990). Transcriptional activation of nitrogen fixation genes in Klebsiella pneumoniae. In Nitrogen Fixation: Achievementi and
Objectives, pp. 451-457. Edited by P. M. Gresshoff, L. E. Roth, G. Stacey \& W. E. Newton. New York: Chapman \& Hall.

Buck, M. \& Cannon, W. (1992). Specific binding of the transcription factor sigma-54 to promoter DNA. Nature 358, 422-424.

Cannon, F. C. (1980). Genetic studies with diazotrophs. In Methods for Evaluating Biological Nitrogen Fixation, pp. 367-413. Edited by F. J. Bergersen. Chichester: John Wiley \& Sons.

Cannon, M., Hill, S., Kavanagh, E. \& Cannon, F. (1985). A molecular genetic study of nif expression in Klebsiella pneumoniae at the level of transcription, translation and nitrogenase activity. Mol \& Gen Genet 198, 198-206.

Dean, D. R. \& Jacobson, M. R. (1992). Biochemical genetics of nitrogenase. In Biological Nitrogen Fixation, pp. 763-834. Edited by G. Stacey, R. H. Burris \& H. J. Evans. New York: Chapman \& Hall.

Dixon, R. A. (1984). The genetic complexity of nitrogen fixation. J Gen Microbiol 130, 2745-2755.

Dixon, R., Eady, R. R., Espin, G., Hill, S., laccarino, M., Kahn, D. \& Merrick, M. (1980). Analysis of regulation of Klebsiella pneumoniae nitrogen fixation (nif) gene cluster with gene fusions. Nature 286, 128-132.

Drummond, M. H. \& Wootton, J. C. (1987). Sequence of nif L from Klebsiella pneumoniae: mode of action and relationship to two families of regulatory proteins. Mol Microbiol 1, 37-44.

Eady, R. R. (1991). The Mo-, V-and Fe-based nitrogenase system of Azotobacter. Adv Inorganic Chem 36, 77-102.

Eady, R. R., Issack, R., Kennedy, C., Postgate, J. R. \& Ratcliffe, H. D. (1978). Nitrogenase of Klebsiella pneumoniae. Comparison of ammonia and oxygen regulation. J Gen Microbiol 104, 277-285.

Filler, W., Kemp, R. M., Ng, J. C., Hawkes, T. R., Dixon, R. A. \& Smith, B. E. (1986). The nifH gene product is required for the synthesis or stability of the iron-molybdenum cofactor of nitrogenase from Klebsiella pneumoniae. Eur J Biochem 160, 371-377.

Filser, M., Merrick, M. \& Cannon, F. C. (1983). Cloning and characterisation of nif $L A$ regulatory mutations from Klebsiella pneumoniae. Mol \& Gen Genet 191, 485-491.

Govezensky, D., Greener, T., Segal, G. \& Zamir, A. (1991). Involvement of GroEL in nif gene regulation and nitrogenase assembly. J Bacteriol 173, 6339-6346.

Hill, S. (1976). Influence of atmospheric oxygen concentration on acetylene reduction and efficiency of nitrogen fixation in intact Klebsiella pneumoniae. J Gen Microbiol 93, 335-345.

Hill, S. (1988). How is nitrogenase regulated by oxygen? FEMS Microbiol Rev 54, 111-130.

Hill, S. (1992). Physiology of nitrogen fixation in free-living heterotrophs. In Biological Nitrogen Fixation, pp. 87-134. Edited by G. Stacey, R. H. Burris \& H. J. Evans. New York: Chapman \& Hall.

Hill, S. \& Kavanagh, E. (1988). Oxygen control and autoregulation of the nif structural operon of Klebsiella pneumoniae involves nitrogenase function. In Nitrogen Fixation: Hundred Years After, p. 309. Edited by H. Bothe, F. J. de Bruijn \& W. E. Newton. Stuttgart: Gustav Fischer.

Hill, S., Turner, G. L. \& Bergersen, F. J. (1984). Synthesis and activity of nitrogenase in Klebsiella pneumoniae exposed to low concentrations of oxygen. J Gen Microbiol 130, 1061-1067.

Hill, S., Viollet, S., Smith, A. T. \& Anthony, C. (1990). Roles for enteric d-type cytochrome oxidase in $\mathrm{N}_{2}$ fixation and microaerobiosis. J Bacteriol 172, 2071-2078.

Hwang, J. C., Chen, C. H. \& Burris, R. H. (1973). Inhibition of 
nitrogenase-catalyzed reductions. Biochim Biophys Acta 292, 339-350.

Jacob, J. \& Drummond, M. (1993). Construction of chimeric proteins from the $\sigma^{\mathrm{N}}$-associated transcriptional activators VnfA and AnfA of Azotobacter vinelandii shows that the determinants of promoter specificity lie outside the 'recognition' helix of the HTH motif in the C-terminal domain. Mol Microbiol 10, 813-821.

Joerger, R. D., Wolfinger, E. D. \& Bishop, P. E. (1991). The gene encoding dinitrogenase reductase 2 is required for expression of the second alternative nitrogenase from Azotobacter vinelandii. J Bacteriol 173, 4440-4446.

Kustu, S., Santero, E., Popham, D. \& Keener, J. (1989). Expression of $\sigma^{54}$ (ntr.4)-dependent genes is probably united by a common mechanism. Microbiol Rev 53, 367-376.

Maniatis, T., Fritsch, E. T. \& Sambrook, J. (1982). Molecular Cloning: A Laboratory Manual. Cold Spring Harbor, NY: Cold Spring Harbor Laboratory.

Merrick, M. J. (1992). Regulation of nitrogen fixation genes in freeliving and symbiotic bacteria. In Biological Nitrogen Fixation, pp. 835-876. Edited by G. Stacey, R. H. Burris \& H. J. Evans. New York: Chapman \& Hall.

Merrick, M. J. (1993). Organization and regulation of nitrogen fixation genes. In New Horizons in Nitrogen Fixation, pp. 43-54. Edited by R. Palacios, J. Mora \& W. E. Newton. Dordrecht: Kluwer Academic Publishers.

Merrick, M., Filser, M., Dixon, R., Elmerich, C., Sibold, L. \& Houmard, J. (1980). The use of translocatable genetic element to construct a fine-structure map of the Klebsiella pneumoniae nitrogen fixation (nif) gene cluster. J Gen Microbiol 117, 509-520.

Merrick, M., Hill, S., Hennecke, H., Hahn, M., Dixon, R. \& Kennedy, C. (1982). Repressor properties of the nifL gene product of Klebsiella pneumoniae. Mol \& Gen Genet 185, 75-81.

Merrick, M. J., Gibbons, J. R. \& Postgate, J. R. (1987). A rapid and efficient method for plasmid transformation of Klebsiella pneumoniae and Escherichia coli. J Gen Microbiol 133, 2053-2057.

Miller, J. H. (1972). Experiments in Molecular Genetics. Cold Spring Harbor, NY: Cold Spring Harbor Laboratory.

Nair, M. \& Eady, R. (1984). Nitrogenase synthesis in Klebsiella pneumoniae: enhanced nif expression without accumulation of guanosine 5'-diphosphate $3^{\prime}$-diphosphate. J Gen Microbiol 130, 3063-3069.

Paul, W. \& Merrick, M. (1989). The roles of the nifW, nif $Z$, and nif $M$ genes of Klebsiella pneumoniae in nitrogenase biosynthesis. Eur $J$ Biochem 178, 675-682.

Postgate, J. R. (1982). The Fundamentals of Nitrogen Fixation. Cambridge: Cambridge University Press.

Smith, A., Hill, S. \& Anthony, C. (1988). A haemoprotein is not involved in the control by oxygen of enteric nitrogenase synthesis. $J$ Gen Microbiol 134, 1499-1507.

Tovey, E. R. \& Baldro, B. A. (1987). Comparison of semi-dry and conventional tank-buffer electrotransfer of protein from polyacrylamide gels to nitrocellulose membranes. Electrophoresis $\mathbf{8}$, 348-387.

Tubb, R. S. \& Postgate, J. R. (1973). Control of nitrogenase synthesis in Klebsiella pneumoniae. J Gen Microbiol 79, 103-117.

Whitehall, S., Austin, S. \& Dixon, R. (1992). DNA supercoiling responses of the $\sigma^{54}$-dependent Klebsiella pneumoniae nif L promoter in vitro. $J$ Mol Biol 225, 591-607.

Young, J. P. W. (1992). Phylogenetic classification of nitrogenfixing organisms. In Biological Nitrogen Fixation, pp. 43-86. Edited by G. Stacey, R. H. Burris \& H. J. Evans. New York: Chapman \& Hall.

Received 22 July 1993; revised 1 December 1993; accepted 8 February 1994. 